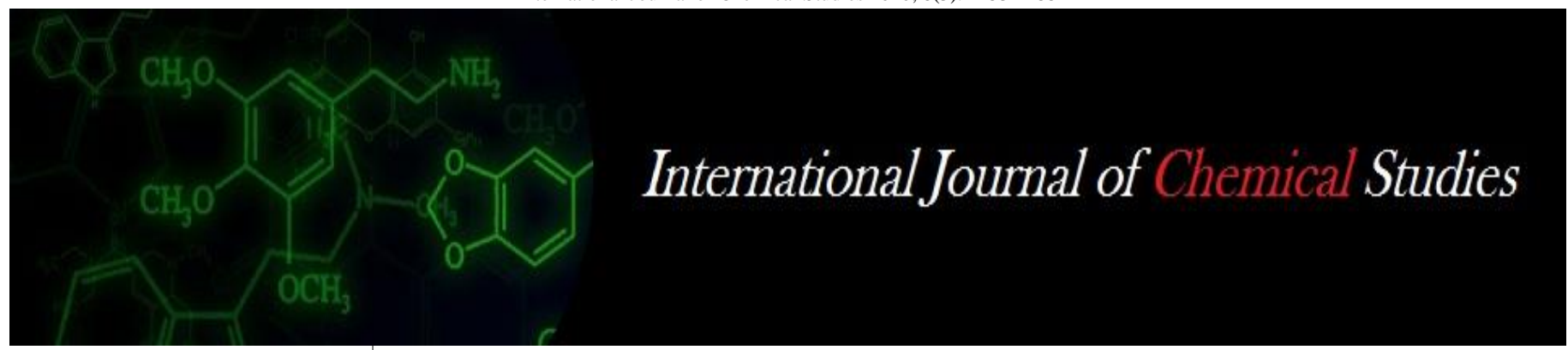

P-ISSN: 2349-8528

E-ISSN: 2321-4902

www.chemijournal.com

IJCS 2020; 8(3): 2253-2255

(C) 2020 IJCS

Received: 22-03-2020

Accepted: 24-04-2020

\section{P Kumari}

M.V.Sc. Scholar, Department of Livestock Production

Management, CVAS, Bikaner,

Rajasthan, India

T Bothra

Assistant Professor, Dept. of

LPM, CVAS, Rajasthan

University of Veterinary and

Animal Sciences, Bikaner,

Rajasthan, India

\section{HK Narula}

Principal Scientist and Head ARC-CSWRI, Bikaner,

Rajasthan, India

\section{Jain}

Assistant Professor, Department of Animal Nutrition, CVAS,

Bikaner, Rajasthan, India

\section{AS Dewna}

Veterinary Officer, Animal

Husbandry Department, Govt.

of Rajasthan, Rajasthan, India

Umesh Kumar Prajapat

Ph.D. Scholar, Dept. of Animal

Nutrition, CVAS, Bikaner,

Rajasthan, India
Corresponding Author:

P Kumari

M.V.Sc. Scholar, Department of

Livestock Production

Management, CVAS, Bikaner,

Rajasthan, India

\section{Effect of Giloy (Tinospora cordifolia) and Neem (Azadirachta indica) on physiological parameters of Marwari lambs under arid zone}

\author{
P Kumari, T Bothra, HK Narula, D Jain, AS Dewna and Umesh Kumar \\ Prajapat
}

DOI: https://doi.org/10.22271/chemi.2020.v8.i3af.9546

\begin{abstract}
The present study was designed with the intention to alleviate the negative effects of heat stress of growing lambs reared under hot environmental conditions. An experiment was conducted to assess the effect of Giloy (Tinospora cordifolia) and Neem (Azadirachta indica) alone and in combination on physiological parameters for 12 weeks on 42 Marwari male lambs and divided into seven groups, six lambs in each group in a randomized block design. The lambs of $\mathrm{T}_{1}$ group were provided only basal diet (grazing $+a d$ lib. fodder $+400 \mathrm{~g}$ concentrate per lamb per day) and were kept as control group and lambs of all other treatment groups were provided basal diet with herbal supplementation i.e. 0.5 per cent Giloy stem powder in group $\mathrm{T}_{2}, 1.0$ per cent Giloy stem powder in group $\mathrm{T}_{3}, 0.5$ per cent Neem leaf powder in group $\mathrm{T}_{4}, 1.0$ per cent Neem leaf powder in group $\mathrm{T}_{5}, 0.25$ per cent Giloy stem powder along with 0.25 per cent Neem leaf powder in group $\mathrm{T}_{6}$ and 0.5 per cent Giloy stem powder along with 0.5 per cent Neem leaf powder in group $\mathrm{T}_{7}$. At the end of experiment, highly significant changes were found in rectal temperature and respiration rate though; they were within normal physiological range. At the end of experiment it appears that incorporation of 0.5 per cent Giloy stem powder along with 0.5 per cent Neem leaves powder can be used as a part of strategy as they are effective to alleviate heat stress in lambs in arid zone of Rajasthan.
\end{abstract}

Keywords: Rectal temperature, respiration rate, giloy, neem, arid zone

\section{Introduction}

One of the major problems facing sheep farming in the arid and semi-arid regions like Rajasthan is the heat stress resulting from high ambient temperature and solar radiation causing the effective temperature of the environment to edge-out the thermo-neutral zone, particularly during summer season (Ali et al., 1999) ${ }^{[1]}$. Environmental temperature above thermo neutral zone negatively affect livestock production and reproductive performance

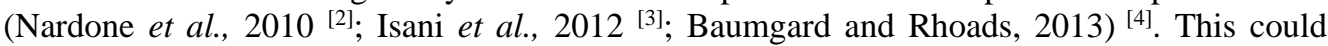
result in a high economic loss for sheep industry. Elevated body temperature, accelerated respiratory and heart rates and post absorptive metabolic changes are the most important characteristic findings for heat stress in ruminants (Bernabucci et al., $2010^{\text {[5] }}$; Al-Haidary et al., $2012^{[6]}$; Abdoun et al., 2012) ${ }^{[7]}$. Several approaches have been used to alleviate heat stress to improve performance in farm animals, including management and feeding strategies. Herbs and their extracts possess a positive impact on physiological functions and help to ensure good health. Herbal supplementation may decrease core body temperature (Tcore) for the short term (Spiers et al., $2004{ }^{[8]}$; Archer et al., 2007) ${ }^{[9]}$ and helps to improve immune function and antioxidant capacity during heat stress. Giloy (Tinospora cordifolia) is a large glabrous deciduous climbing shrub belonging to family Menispermaceae. Giloy is widely used in ethno medicine for its general tonic, antioxidant, antibacterial, immunomodulator, hepatoprotective and anti-inflammatory properties (Krishna et al., 2009) ${ }^{[10]}$. Anti stress activity of Giloy evaluated by Devasena and Adilaxmamma (2014) ${ }^{[11]}$ as reported significant reduction in reduced glutathione and superoxide dismutase activity in erythrocytes of goat when treated with Giloy. It is claimed that the plant climbing up the Neem tree is said to be the best as synergy between these two bitter plants enhances Giloy`s efficacy. 
Neem (Azadirachta indica) belongs to the family Meliaceae. Research has shown that Neem boost the immune system by stimulating the production of T-cells when faced with infections (Upadhyay, 1990) ${ }^{[12]}$

To our knowledge, there is a lack of information pertaining to dietary inclusion of Giloy (Tinospora cordifolia) alone and in combination with Neem (Azadirachta indica) to the growing lambs; therefore, the objective of the present study was to evaluate the ability of Giloy and Neem to alleviate the effects of heat stress in growing lambs under hot summer conditions.

\section{Materials and Methods}

The present study was conducted on Marwari lambs maintained at Arid Region campus of Central Sheep and Wool Research Institute (ICAR-ARC-CSWRI), Bikaner. The average rainfall is low $(250 \mathrm{~mm})$ and erratic. The temperature varies between sub zero $\left(-2{ }^{\circ} \mathrm{C}\right)$ during winter and high $(49$ ${ }^{\circ} \mathrm{C}$ ) during summer. The experiment was conducted from May to July, 2019. Meteorological data viz. temperature and relative humidity were collected from Agriculture Research Station, Bikaner from May 2019 to July 2019 at weekly intervals. THI values were calculated from recorded meteorological variables as described below by formula given by Marai et al. (2007) ${ }^{[13]}$.

$\mathrm{THI}=\mathrm{db}^{\circ} \mathrm{C}-\left[(0.31-0.31 \mathrm{RH})\left(\mathrm{db}^{\circ} \mathrm{C}-14.4\right)\right]$

$\mathrm{THI}=$ Temperature humidity index

$\mathrm{db}=$ Dry-bulb temperature $\left({ }^{\circ} \mathrm{C}\right)$

$\mathrm{RH}=$ Relative humidity as fraction of a unit (\%)

Forty-two growing male Marwari lambs (3-4 months old) were divided into seven groups $\mathrm{T}_{1}, \mathrm{~T}_{2}, \mathrm{~T}_{3}, \mathrm{~T}_{4}, \mathrm{~T}_{5}, \mathrm{~T}_{6}$ and $\mathrm{T}_{7}$ having six lambs in each group on body weight basis. The lambs of $\mathrm{T}_{1}$ group were provided only basal diet (grazing for a period of 8 hours + ad lib. fodder $+400 \mathrm{~g}$ concentrate per lamb per day) and were kept as control group. The lambs of $\mathrm{T}_{2}$ group were provided basal diet supplemented with 0.5 per cent Giloy stem powder. The lambs of $T_{3}$ group were provided basal diet supplemented with 1.0 per cent Giloy stem powder. The lambs of $\mathrm{T}_{4}$ group were provided basal diet supplemented with 0.5 per cent Neem leaf powder. The lambs of $\mathrm{T}_{5}$ group were provided basal diet supplemented with 1.0 per cent Neem leaf powder. The lambs of $T_{6}$ group were provided basal diet supplemented with 0.25 per cent Giloy stem powder and 0.25 per cent Neem leaf powder. The lambs of $\mathrm{T}_{7}$ group were provided basal diet supplemented with 0.5 per cent Giloy stem powder and 0.5 per cent Neem leaf powder. Physiological variables viz., rectal temperature and respiration rate of lambs were recorded at fortnightly intervals. The rectal temperature was measured by a digital clinical thermometer in degree Fahrenheit $\left({ }^{0} \mathrm{~F}\right)$. The respiration rate was recorded by observing flank movement for one minute in which each inward and outward movement of the flank was counted as one complete respiration. The respiration rate was expressed as breaths per minute (bpm). The data obtained in the study was analyzed in one-way ANOVA using SPSS 20.00 statistical analysis software.

\section{Results and Discussion}

The values of average temperature $\left({ }^{\circ} \mathrm{C}\right)$, average relative humidity $(\%)$ and average THI at weekly intervals have been presented in Table 1. Marai et al. (2007) ${ }^{[13]}$ established THI threshold of 25.6 for sheep. In present study, the calculated THI values revealed that the experimental lambs were in extreme severe heat stress, during the course of experiment. The mean values of rectal temperature of lambs in ${ }^{\circ} \mathrm{F}$ under different treatment groups at fortnightly intervals of experiment have been presented in Table 2 . The mean values of rectal temperature $\left({ }^{\circ} \mathrm{F}\right)$ varied from $102.62^{\circ} \mathrm{F}$ ( $5^{\text {th }}$ fortnight $)$ to $103.37^{\circ} \mathrm{F}$ (zero day) in $\mathrm{T}_{1}, 101.3^{\circ} \mathrm{F}$ ( $6^{\text {th }}$ fortnight) to $103.45^{\circ} \mathrm{F}$ (zero day) in $\mathrm{T}_{2}, 101.1^{\circ} \mathrm{F}$ ( $6^{\text {th }}$ fortnight) to $103.44^{\circ} \mathrm{F}$ (zero day) in $\mathrm{T}_{3}, 101.82^{\circ} \mathrm{F}$ ( $5^{\text {th }}$ fortnight) to $103.42^{\circ} \mathrm{F}$ (zero day) in $\mathrm{T}_{4}, 101.67^{\circ} \mathrm{F}$ ( $5^{\text {th }}$ fortnight) to $103.47^{\circ} \mathrm{F}$ (zero day) in $\mathrm{T}_{5}, 100.94^{\circ} \mathrm{F}$ ( $6^{\text {th }}$ fortnight) to $103.37^{\circ} \mathrm{F}$ (zero day) in $\mathrm{T}_{6}$ and $100.75^{\circ} \mathrm{F}$ ( $6^{\text {th }}$ fortnight) to $103.37^{\circ} \mathrm{F}$ (zero day) in $\mathrm{T}_{7}$ group. The statistical analysis of variance revealed significant $(P<0.05)$ effect on mean rectal temperature of lambs at $4^{\text {th }}$ fortnight, whereas, highly significant $(P<0.01)$ at $5^{\text {th }}, 6^{\text {th }}$ fortnight and on average rectal temperature of whole experiment. The mean values of respiration rate of lambs in breaths per minute under different treatment groups at fortnightly intervals of experiment have been presented in Table 3 . The mean values of respiration rate (breaths/minute) varied from 71.34 ( $4^{\text {th }}$ fortnight) to 79.84 ( $1^{\text {st }}$ fortnight $)$ in $T_{1}$, $62.67\left(6^{\text {th }}\right.$ fortnight) to 76.50 (zero day) in $T_{2}, 59.5\left(6^{\text {th }}\right.$ fortnight) to 77.17 (zero day) in $\mathrm{T}_{3}, 62.00$ ( $6^{\text {th }}$ fortnight) to 77.00 (zero day) in $\mathrm{T}_{4}, 59.17$ ( $6^{\text {th }}$ fortnight) to 78.84 (zero day) in $\mathrm{T}_{5}, 58.50$ ( $6^{\text {th }}$ fortnight) to 78.00 (zero day) in $\mathrm{T}_{6}$ and 57.50 ( $6^{\text {th }}$ fortnight) to 76.84 (initial) in $T_{7}$ group. The statistical analysis of variance revealed significant $(P<0.05)$ effect on mean respiration rate of lambs in $1^{\text {st }}$ fortnight, whereas, highly significant $(P<0.01)$ effect was observed in $5^{\text {th }}$ and $6^{\text {th }}$ fortnight. Non-significant effect was observed for rest of the fortnights as well as on average respiration rate of whole trial. The obtained results indicated that there were fluctuations in physiological responses of lambs i.e. rectal temperature and respiration rate which varied with the changes in the environmental temperature. Results of present findings showed that there was highly significant reduction in average rectal temperature and respiration rate in treatment groups compared to control. The present findings were similar with Al-Ramadan and Alamer (2010) ${ }^{[14]}$ who reported significant reduction in rectal temperature and respiration rate in sheep supplemented with herb Sisymbrium irio and also indicated that Sisymbrium irio was effective to alleviate heat stress in sheep. In sheep, panting is the major evaporatory heat loss mechanism and respiratory frequencies tend to follow closely the heat loss by evaporation (Marai et al., 2007) [13]. This physiological adjustment is essential to maintain normal body temperature and to prevent hyperthermia (Lowe et al., 2001 [15]; Baumgard and Rhoads, 2013) ${ }^{[4]}$. Hence, the observed lower respiration rate and rectal temperature in lambs supplemented with Giloy stem powder and Neem leaves powder indicates that they were not under heat stress compared to lambs of control group which were not supplemented with Giloy stem powder and Neem leaves powder. It might be due to anti stress activity of Giloy.

Table 1: Temperature $\left({ }^{\circ} \mathrm{C}\right)$, Relative humidity $(\%)$ and THI

\begin{tabular}{|c|c|c|c|}
\hline Weeks & Temperature $\left({ }^{\circ} \mathbf{C}\right)$ & Relative humidity (\%) & THI \\
\hline 1 & 33.6 & 59.0 & 31.15 \\
\hline 2 & 30.6 & 44.1 & 27.78 \\
\hline 3 & 33.8 & 54.6 & 31.04 \\
\hline 4 & 39.5 & 83.9 & 38.20 \\
\hline 5 & 38.2 & 82.4 & 36.93 \\
\hline 6 & 37.1 & 61.5 & 34.40 \\
\hline 7 & 34.1 & 79.4 & 32.85 \\
\hline 8 & 34.3 & 77.1 & 32.87 \\
\hline 9 & 36.4 & 87.9 & 35.58 \\
\hline 10 & 34.6 & 54.5 & 31.79 \\
\hline 11 & 33.7 & 56.5 & 31.10 \\
\hline 12 & 32.0 & 64.9 & 30.10 \\
\hline Average & 34.8 & 67.1 & 32.74 \\
\hline
\end{tabular}


Table 2: Rectal temperature $\left({ }^{\circ} \mathrm{F}\right)$ of lambs at fortnightly intervals in different treatment groups

\begin{tabular}{|c|c|c|c|c|c|c|c|c|}
\hline \multirow{2}{*}{$\begin{array}{c}\text { Treatment } \\
\text { groups }\end{array}$} & \multicolumn{8}{|c|}{ Periods (fortnights) } \\
\hline & $\mathbf{0}$ & $\mathbf{I}$ & II & III & IV & $\mathbf{V}$ & VI & Average \\
\hline $\mathrm{T}_{1}$ & 103.37 & 103.25 & 103.20 & 103.14 & 102.79 & $102.62^{\mathrm{B}}$ & $102.69^{c}$ & $103.01^{\mathrm{b}}$ \\
\hline $\mathrm{T}_{2}$ & 103.45 & 103.20 & 103.15 & 102.74 & 102.22 & $101.94^{\mathrm{AB}}$ & $101.30^{\mathrm{b}}$ & $102.57^{\mathrm{a}}$ \\
\hline $\mathrm{T}_{3}$ & 103.44 & 103.14 & 102.92 & 102.95 & 102.27 & $101.87^{\mathrm{AB}}$ & $101.10^{\mathrm{ab}}$ & $102.53^{\mathrm{a}}$ \\
\hline $\mathrm{T}_{4}$ & 103.42 & 103.25 & 103.32 & 102.82 & 102.75 & $101.82^{\mathrm{A}}$ & $100.84^{\mathrm{ab}}$ & $102.60^{\mathrm{a}}$ \\
\hline $\mathrm{T}_{5}$ & 103.47 & 103.25 & 103.35 & 103.09 & 102.67 & $101.67^{\mathrm{A}}$ & $100.70^{\mathrm{a}}$ & $102.60^{\mathrm{a}}$ \\
\hline $\mathrm{T}_{6}$ & 103.37 & 103.29 & 103.17 & 103.14 & 102.39 & $101.30^{\mathrm{A}}$ & $100.94^{\mathrm{ab}}$ & $102.51^{\mathrm{a}}$ \\
\hline $\mathrm{T}_{7}$ & 103.37 & 103.22 & 103.17 & 102.94 & 102.25 & $101.42^{\mathrm{A}}$ & $100.75^{\mathrm{a}}$ & $102.45^{\mathrm{a}}$ \\
\hline SEM & 0.12 & 0.11 & 0.10 & 0.17 & 0.22 & 0.25 & 0.17 & 0.10 \\
\hline
\end{tabular}

Note: Means with different superscripts $(\mathrm{A}, \mathrm{B})$ in a column differ significantly $(p<0.01)$, Means with different superscripts $(\mathrm{a}, \mathrm{b})$ in a column differ significantly $(p<0.05)$

Table 3: Respiration rate (breaths per min) of lambs at fortnightly intervals in different treatment group

\begin{tabular}{|c|c|c|c|c|c|c|c|c|}
\hline \multirow{2}{*}{$\begin{array}{c}\text { Treatment } \\
\text { groups }\end{array}$} & \multicolumn{7}{|c|}{ Periods (fortnights) } \\
\cline { 2 - 9 } & $\mathbf{0}$ & I & II & III & IV & V & VI & Average \\
\hline $\mathrm{T}_{1}$ & 76.67 & $79.84^{\mathrm{c}}$ & 76.17 & 74.17 & 71.34 & $73.67^{\mathrm{B}}$ & $73.34^{\mathrm{b}}$ & 75.03 \\
\hline $\mathrm{T}_{2}$ & 76.50 & $72.67^{\mathrm{abc}}$ & 71.34 & 69.67 & 68.84 & $63.84^{\mathrm{A}}$ & $62.67^{\mathrm{a}}$ & 69.36 \\
\hline $\mathrm{T}_{3}$ & 77.17 & $74.34^{\mathrm{bc}}$ & 73.50 & 69.17 & 66.17 & $62.67^{\mathrm{A}}$ & $59.50^{\mathrm{a}}$ & 68.93 \\
\hline $\mathrm{T}_{4}$ & 77.00 & $74.50^{\mathrm{bc}}$ & 72.17 & 68.34 & 66.84 & $63.84^{\mathrm{A}}$ & $62.00^{\mathrm{a}}$ & 69.24 \\
\hline $\mathrm{T}_{5}$ & 78.84 & $75.00^{\mathrm{bc}}$ & 72.17 & 68.67 & 66.67 & $62.50^{\mathrm{A}}$ & $59.17^{\mathrm{a}}$ & 69.00 \\
\hline $\mathrm{T}_{6}$ & 78.00 & $69.17^{\mathrm{ab}}$ & 71.84 & 66.00 & 65.00 & $60.34^{\mathrm{A}}$ & $58.50^{\mathrm{a}}$ & 66.98 \\
\hline $\mathrm{T}_{7}$ & 76.84 & $65.34^{\mathrm{a}}$ & 66.67 & 62.17 & 60.67 & $58.50^{\mathrm{A}}$ & $57.50^{\mathrm{a}}$ & 63.96 \\
\hline $\mathrm{SEM}^{\mathrm{SE}}$ & 3.26 & 2.67 & 2.78 & 2.58 & 2.72 & 2.32 & 2.50 & 2.47 \\
\hline
\end{tabular}

Note: Means with different superscripts $(\mathrm{A}, \mathrm{B})$ in a column differ significantly $(p<0.01)$, Means with different superscripts $(\mathrm{a}, \mathrm{b})$ in a column differ significantly $(p<0.05)$

\section{Conclusion}

Supplementation of Giloy (Tinospora cordifolia) and Neem (Azadirachta indica) may be a positive indicator of immune response and effective to control heat stress condition in lambs. At the end, based on the physiological parameters viz. rectal temperature and respiration rate of lambs, it appears that incorporation of 0.5 per cent Giloy stem powder along with 0.5 per cent Neem leaves powder can be used as a part of strategy to be adopted to alleviate heat stress of growing lambs in arid zone of Rajasthan.

\section{Acknowledgement}

We gratefully acknowledge the help offered by Dean, College of Veterinary and Animal Science, Bikaner and Head, ARCCSWRI, Bikaner for providing infrastructure and necessary facilities to conduct the research.

\section{References}

1. Ali AK, Al-Haidary AA, Al-Shaikh MA, Hayes E. The Effect of evaporative cooling in alleviating seasonal differences in milk production of Almarai farms in the Kingdom of Saudi Arabia. Asian-Australasian Journal of Animal Sciences. 1999; 4:590-596.

2. Nardone A, Ronchi B, Lacetera N, Ranieri MS, Bernabucci U. Effects of climate changes on animal production and sustainability of livestock systems. Livestock Science. 2010; 130:57-69.

3. Isani GB, Yaqoob M, Khan BB, Younas M, Hanjra SH. A comparative study of effect of docking fat-tailed sheep and crossbreeding fat-tailed and thin-tailed sheep on growth and carcass characteristics. Pakistan Journal of Agricultural Sciences. 2012; 49:87-93.

4. Baumgard LH, Rhoads RP Jr. Effects of heat stress on postabsorptive metabolism and energetics. Annual Review of Animal Biosciences. 2013; 1:311-337.
5. Bernabucci U, Lacetera N, Baumgard LH, Rhoads RP, Ronchi B, Nardone A et al. Metabolic and hormonal acclimation to heat stress in domesticated ruminants. Animal. 2010; 4:1167-1183.

6. Al-Haidary AA, Aljumaah RS, Alshaikh MA, Samara EM, Abdoun KA, Okab AB et al. Thermoregulatory and physiological responses of Najdi sheep exposed to environmental heat load prevailing in Saudi Arabia. Pakistan Veterinary Journal. 2012; 32:515-519.

7. Abdoun KA, Samara EM, Okab AB, Al-Haidary AA. A comparative study on seasonal variation in body temperature and blood composition of camels and sheep. Journal of Animal and Veterinary Advances. 2012; 11:769-773.

8. Spiers DE, Eichen PA, Leonard MJ, Wax LE, Rottinghaus GE, Williams JE et al. Benefit of dietary seaweed (Ascophyllum nodosum) extract in reducing heat strain and fescue toxicosis: A comparative evaluation. Journal of Thermal Biology. 2004; 29:753-757.

9. Archer GS, Friend TH, Caldwell D, Ameiss K, Krawczel PD. Effect of the seaweed Ascophyllum nodosum on lambs during forced walking and transport. Journal of Animal Science. 2007; 85:225-232.

10. Krishna K, Jigar B, Jagruti P. Guduchi (Tinospora cordifolia): biological and medicinal properties, a review. The Internet Journal of Alternative Medicine. 2009; 6(2):1-12.

11. Devasena B, Adilaxmamma K. Anti-stress activity of Tinospora cordifolia in goats maintained under different managemental conditions. Indian Journal of Small Ruminants. 2014; 20(1):104-107.

12. Upadhyay C. The medicinal properties of Neem (Azadirachta indica) tree. In: Animal Pharmacology. Second Edition Longman England, 1990.

13. Marai IFM, El-Darawany AA, Fadiel A, Abdel-Hafez MAM. Physiological traits as affected by heat stress in sheep-A review. Small Ruminant Research. 2007; 71(13):1-12.

14. Al-Ramadan MM, Alamer MA. The effect of utilizing certain medicinal herbs for the alleviation of heat stress in Awassi sheep. Arab Gulf Journal of Scientific Research. 2010; 28(4):224-230.

15. Lowe TE, Cook CJ, Ingram JK, Harris PJ. Impact of climate on thermal rhythm in pastoral sheep. Physiology and Behaviour. 2001; 74(4-5):659-664. 